\title{
Numerical Analysis of Ampicillin Release from Electrospun Nanofibrous Mats
}

\author{
Mehmet Melih TATLISÖZ ${ }^{1}$, Çetin CANPOLAT ${ }^{* 1}$ \\ ${ }^{1}$ Çukurova Üniversitesi, Mühendislik Fakültesi, Biyomedikal Mühendisliği Bölümü, Adana
}

Geliş tarihi: 15.02.2021 Kabul tarihi: 31.03 .2021

\begin{abstract}
The electrospun nanofibrous mat is an emerging tool for drug release studies. Therefore, it is essential to predict this type of system's drug release behavior to overcome the existing problems and generate novel drug release systems. In the present work, a numerical study is performed for fulfilling this requirement, and the current numerical data is validated with the experimental study, which is available in the open literature. Transient Langmuir-Freundlich adsorption-desorption isotherm is employed for describing the drug release behavior of the electrospun nanofibrous system under perfect sink conditions. The effect of the diffusion phenomenon is also taken into account. Drug release rates are investigated for different initial drug concentrations, porosity values, permittivity mass coefficients, and mat surface areas. Moreover, the relationship between the porosity and the initial drug concentration is also presented. It can be reported that significant alterations occur in drug release rates through varied initial drug concentrations and porosity. Although the drug release rate is altered with permittivity coefficient or surface area, minor variations are observed compared to the parameters above. The results of the numerical code agree well with the experimental data.
\end{abstract}

Anahtar Kelimeler: Controlled drug release, Electrospinning, Nanofibrous mat, Numerical analysis, Adsorption-desorption kinetics

\section{Electrospun Nanofibröz Matlardan Ampisilin Salımının Sayısal Analizi}

Öz

Elektrospun nanofibröz mat, ilaç salım çalışmaları için güncel bir tekniktir. Bu nedenle, mevcut sorunların üstesinden gelmek ve yeni ilaç salım sistemleri oluşturmak için bu tür sistemlerin ilaç salım davranışını incelemek önemlidir. Bu makalede, bu gerekliliğin karşılanması için sayısal bir çalışma yapılmış ve mevcut sayısal veriler literatürde bulunan deneysel çalışma sonuçları ile doğrulanmıştır. Geçici Langmuir-Freundlich adsorpsiyon-desorpsiyon izotermi, elektrospun nanofibröz sistemin mükemmel kuyu koşulları altında ilaç salım davranışını açıklamak için kullanılmıştır. Difüzyonun etkisi de hesaba katılmıştır. İlaç salım oranları, farklı ilk ilaç konsantrasyonları, gözenek değerleri, geçirgenlik kütle katsayıları ve mat yüzey alanları için araştırılmıştır. Ayrıca gözenek ve ilk ilaç konsantrasyonu arasındaki ilişki de bu çalışmada verilmiştir. Çeşitli başlangıç ilaç konsantrasyonları ve gözenekler

*Sorumlu yazar (Corresponding author): Çetin CANPOLAT, ccanpolat@cu.edu.tr 
vasıtasıyla ilaç salım oranlarında bazı önemli değişikliklerin meydana geldiği görülmüştür. İlaç salım hızı, geçirgenlik katsayısı veya yüzey alanı ile değişmekle birlikte, bu değişimlerde yukarıda bahsedilen parametrelere göre küçük farklılıklar gözlenmektedir. Sayısal kodun sonuçları deneysel verilerle uyumludur.

Keywords: Kontrollü ilaç salımı, Elektrospinning, Nanofibröz mat, Sayısal analiz, Adsorpsiyondesorpsiyon kinetiği

\section{INTRODUCTION}

Various advantages of extending drug release in the human body, such as decreased fluctuations of the active component in the bloodstream [1], lower duration of administration [2], improved patient enforcement [3] are present. In order to prolong the active ingredient's efficacy, many medicinal and chemical precautions are recommended. For instance, adsorption time can be increased by modifying the medication's administration type [4], biotransformation can be prevented through introducing enzymatic inhibitors to the drug composition [5], and vasoconstrictor compounds may postpone the extraction of the active ingredient from the body [6]. The most effective and healthy method is changing the type of active ingredient's release form [7].

Electrospinning is a versatile process for generating continuous fibers with diameters ranging from nano- to micro-scale [8]. In this process, an external electrical field is applied to the hemispherical solution drop at the edge of the nozzle. Taylor cone is formed along with increasing external electrical field [9]. After a threshold value, the fluid's surface tension is exceeded by electrostatic repulsive forces, which leads to the ejection of a solidified single fluid jet from the tip of the Taylor cone [10]. A single fluid jet is splayed into fibers as traveling through the applied electrical field [11]. Splayed fibers are randomly or uniformly deposited on the grounded scaffold; thus, a nanofibrous mat is generated. Some remarkable advantages of electrospinning exist, such as the fabrication of nanofibers with large surface areas, good mechanical properties, and easy surface functionalization [12]. Therefore, electrospinning becomes a popular technique throughout diverse professions, such as textile engineering [13], food engineering [14], pharmaceutics [15], electronics [16], optics [17], and biomedical engineering [18]. From a biomedical engineering perspective, electrospinning is utilized in the fields of biomaterials [19], biosensors [20], tissue engineering [21], and medical imaging [22]. The advantages of electrospun nanofibers in pharmaceutics are high drug loading capacity, controllable microstructure and positional deposition of components, enabling simultaneous delivery of different therapeutics, and low costs [23]. Moreover, location-specific drug delivery, high solubility of hydrophobic drugs, prevention of degradation of biomolecules can be achieved with electrospinning, in contrast to conventional drug release systems [24]. Due to these capabilities and advantages, the drug release from electrospun nanofibers is conducted and proposed in the literature. Tetracycline hydrochloride release from electrospun fibers is investigated and compared with commercial drug release systems by Kenawy et al. [25]. Zeng et al. [26] conduct a comparative study between coated and uncoated nanofibers according to drug release behaviors. Cui et al. [27] utilizes electrospun nanofibers as drug delivery vehicles. Thakur et al. [28] fabricate a nanofiber scaffold by electrospinning and employ it as a drug release system, etc.

Most studies are performed experimentally in the drug release studies for nanofiber mats. To the best of the authors' knowledge, mathematical modeling for nanofibrous drug release is included only in three studies, which are Nakielski et al. [28], Lin et al. [29], and Petlin et al. [30]. While numerical analysis is utilized for verifying experimental drug release behavior by the first and the second studies, the effect of nanofiber diameter distribution on drug release rate is investigated mechanistically in the work of Petlin et al. [29]. However, influences of many parameters 
associated with the electrospinning technique are still unknown. At this point, mathematical modeling comes into play as a useful tool to handle physical problems due to its low time, labor burden and high accuracy. Mathematical models of drug release can be mainly categorized as empirical/semi-empirical and mechanistic. Although structural connectivity and functional mechanisms are known for mechanistic modeling, empirical/semi-empirical modeling is governed by the system's external parameter, namely the drug release rate.

In the current numerical study, the comprehensive numerical analyses are provided for the parameters of electrospinning affecting the drug release rate, such as initial drug concentration, the porosity of nanofibrous mat, and permittivity coefficient between the nanofibrous mat and release medium, size of the nanofibrous mat. Moreover, the impact of porosity and the nanofibrous mat size on initial drug concentration is also presented. For the validation purposes of mathematical model, the experimental results of Sultanova et al. [30] are utilized.

\section{MATERIAL AND METHODS}

\subsection{Theory}

Drug release from nanofibrous mats are described with transient Langmuir - Freundlich adsorptiondesorption isotherm (Equation 1):

$$
\frac{d C_{A}}{d t}=k_{a d s}\left(C_{A 0}-C_{A}\right) C_{B}-k_{d e s} C_{A}
$$

where drug adsorbed on the fiber surface is represented by $\mathrm{C}_{\mathrm{A}}(\mathrm{kg} / \mathrm{kg}), \mathrm{C}_{\mathrm{B}}$ is the desorbed drug concentration $(\mathrm{kg} / \mathrm{m} 3)$, and $\mathrm{C}_{\mathrm{A} 0}$ represents the initial adsorbed drug concentration. $\mathrm{k}_{\mathrm{ads}}\left(\mathrm{m}^{3} / \mathrm{kg} . \mathrm{s}\right)$ and $\mathrm{k}_{\mathrm{des}}(1 / \mathrm{s})$ are adsorption rate constant and desorption rate constant, respectively.

After the desorption process, free drug molecules are removed from the nanofibrous surface through the diffusion phenomenon. Rectangular coordinates are preferred for describing the transport of free drug molecules. Note that the diffusion coefficient of the modeled drug is assumed constant. The change of the desorbed drug concentration with time can be governed by the equation below (Equation 2).

$\frac{d C_{B}}{d t}=D_{B}\left(\frac{\partial^{2} C_{B}}{d x^{2}}+\frac{\partial^{2} C_{B}}{d y^{2}}\right)-\frac{1-\varepsilon}{\varepsilon} \rho_{p} \frac{d C_{A}}{d t}$

where $\varepsilon$ is the porosity of nanofibrous mat and $\rho p$ is the density of polymer $\left(\mathrm{kg} / \mathrm{m}^{3}\right)$. A nanofibrous mat is assumed to be placed in a perfect sink medium. Therefore, perfect sink condition is applied upon the boundaries of the nanofibrous mat (Equation 3):

$$
J_{B}=k_{c}\left(C_{B, \text { medium }}-C_{B}\right)
$$

where $J_{B}$ is the flux of the desorbed molecule, $k_{c}$ is the permittivity coefficient $(\mathrm{m} / \mathrm{s}), \mathrm{C}_{\mathrm{B}}$, the medium is the desorbed molecule concentration in the surrounding medium and equal to zero, due to the perfect sink condition. The drug release rate is calculated according to the ratio of remaining drug mass inside the computational domain and initial drug mass, as shown (Equation 4):

$$
D R R=1-\frac{\int_{V} C_{A}((1-\varepsilon) / \varepsilon) \rho_{p} d v}{\int_{V} C_{A 0}((1-\varepsilon) / \varepsilon) \rho_{p} d v}
$$

As seen in the equation 4, the drug release mechanism is primarily based on the adsorptiondesorption process. $\mathrm{C}_{\mathrm{A}}$ and $\mathrm{C}_{\mathrm{A} 0}$ are multiplicated by the equation of $((1-\varepsilon) / \varepsilon) \rho_{p}$ for converting the mass concentration term $(\mathrm{kg} / \mathrm{kg})$ to the volumetric concentration term $\left(\mathrm{kg} / \mathrm{m}^{3}\right)$. In addition, the drug release mechanism is also affected by the concentration of desorbed drug molecules, the diffusion coefficient of the model drug, and the permittivity coefficient of the interface between the nanofibrous mat and the release medium.

\subsection{Numerical Analysis}

First of all, the study by Sultanova et al.,[30] is used to validate the initial results of the current 
numerical simulation. In their study, ampicillin and polycaprolactone (PCL) are the drug and the polymer, respectively. Drug release is carried out in phosphate-buffered saline (PBS, at $\mathrm{pH}:$ 7.4) medium. The experimental result of the drug release rate is exploited to determine the model parameters. By this means, an excellent alignment is established between the experimental and the numerical results. Simulations are performed via COMSOL Multiphysics 5.3a software. The nanofibrous mat is constructed as a tetragonal prism with a width of $\mathrm{W}=1.5 \mathrm{~cm}$, a length of $\mathrm{L}=1.5 \mathrm{~cm}$, and a height of $\mathrm{H}=0.025 \mathrm{~cm}$, as depicted in Figure 1a. Due to the physics of the problem, the nanofibrous mat used in our numerical model is created in two dimensions (2D), as shown in Figure $1 \mathrm{~b}$ since nanofibrous mats have a relatively

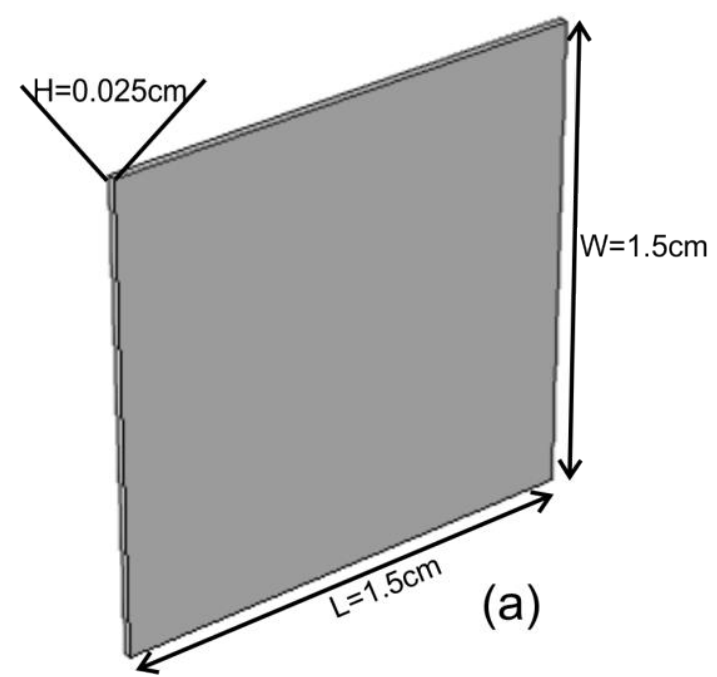

Figure 1. (a) Nanofibrous mat dimensions in 3D (b)

\section{RESULTS AND DISCUSSION}

Since the required modeling parameter values for ampicillin and PCL are not available, we first focus on determining these parameters in this study. A strong correlation with $\mathrm{r}=0.9815$ is observed between the experimental and numerical results, as shown in Figure 2. Therefore, adsorption rate constant, desorption rate constant, diffusion coefficient of desorbed drug and permittivity constant at the interface are determined as $\mathrm{k}_{\mathrm{ads}}=5 \times 10^{-8} \mathrm{~m}^{3} /(\mathrm{kg} . \mathrm{s}), \mathrm{k}_{\mathrm{des}}=2.3 \times 10^{-4}$ low thickness (typically a few hundred micrometers). Therefore, the numerical model can provide acceptable results with the experimental data. Moreover, nanofibers are assumed to be nondegradable in numerical analyses. PCL degrades fully in a period of 60 months in PBS media [31], which is a very long time scale for our simulations; thus, degradation can be safely ignored in this work. The computational domain has a mesh structure with triangular elements. A convergence analysis is carried out to determine the optimum mesh element number. The problem is solved with meshes having 366, 574, 1308 and 2124 elements. The relative error between 574- and 1308-element meshes is observed to be lower than $0.1 \%$. Therefore, 574-element mesh is taken to be optimal for this study.

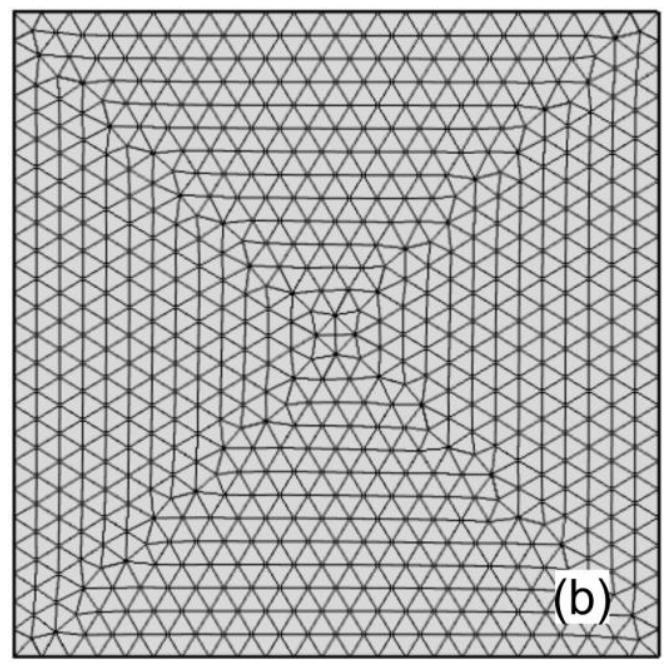

b) $2 \mathrm{D}$ computational domain with applied mesh

$1 / \mathrm{s}, D_{B}=1 \times 10^{-10} \mathrm{~m}^{2} / \mathrm{s}, \mathrm{k}_{\mathrm{c}}=7 \times 10^{-8} \mathrm{~m} / \mathrm{s}$, respectively. In the experimental study, the nanofibrous mats' mass is given as $100 \mathrm{mg}$ and drug concentration is five times lower than polymer concentration, which yields $\mathrm{C}_{\mathrm{A} 0}=0.2$. Hence, the initial drug mass is determined as $16.667 \mathrm{mg}$. In order to obtain the initial drug mass, which is aimed to be consistent with the experimental results, the porosity value as shown in the denominator of Equation 4 is adjusted to 0.436 . The density of PCL is a known value and equals to $\rho_{\mathrm{p}}=1145 \mathrm{~kg} / \mathrm{m}^{3}$. All parameters used for the simulations are listed in Table 1. 


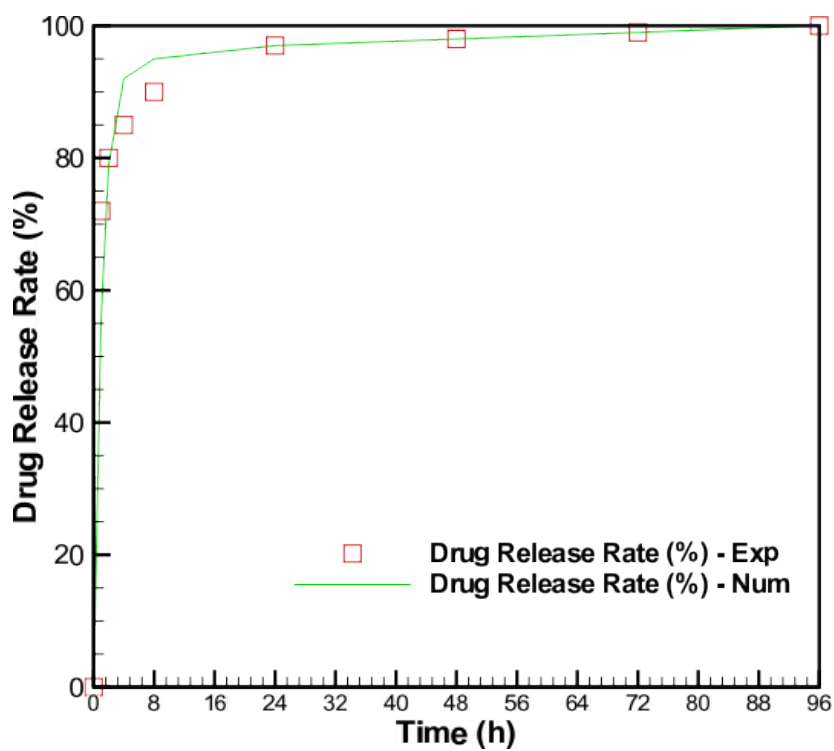

Figure 2. Comparison of drug release rates between the experimental study of Sultanova et al. [30] and our numerical results

Table 1. Parameters used during the numerical analyzes

\begin{tabular}{|l|l|l|}
\hline Symbol & Definition & Values \\
\hline $\mathrm{k}_{\mathrm{ads}}$ & Adsorption rate constant of the model drug & $5 \times 10^{-8} \mathrm{~m}^{3} / \mathrm{kg} . \mathrm{s}$ \\
\hline $\mathrm{k}_{\mathrm{des}}$ & Desorption rate constant of the model drug & $2.3 \times 10^{-4} 1 / \mathrm{s}$ \\
\hline $\mathrm{C}_{\mathrm{AO}}$ & Initial adsorbed drug concentration & $0.05-0.1-0.2-0.4-0.8 \mathrm{~kg} / \mathrm{kg}$ \\
\hline$\varepsilon$ & Porosity of the nanofibrous mat & $0.216-0.436-0.654-0.872$ \\
\hline $\mathrm{D}$ & Diffusion coefficient of the model drug & $1 \times 10^{-10} \mathrm{~m}^{2} / \mathrm{s}$ \\
\hline $\mathrm{k}_{\mathrm{c}}$ & Permittivity coefficient & $3.5 \times 10^{-8}-7 \times 10^{-8}-1.4 \times 10^{-7} \mathrm{~m} / \mathrm{s}$ \\
\hline
\end{tabular}

Adsorbed drug concentration, depicted in Figure 3, demonstrates that the loaded drug is uniformly adsorbed on the nanofiber surface initially. When the release process starts, the drug is desorbed and transported out of the nanofibrous mat. During the process, the uniform distribution of the drug is roughly maintained. Concentration diminishes slightly in the horizontal and vertical directions. When a drug concentration of $296.18 \mathrm{~kg} / \mathrm{m}^{3}$ is loaded, the only drug in the amount of $24.156 \mathrm{~kg} / \mathrm{m}^{3}$ remains after $\mathrm{t}=4 \mathrm{~h}$. This result is consistent with the inevitable burst release behavior of nanofibrous membranes. The drug release rate is attenuated for $\mathrm{t}=8 \mathrm{~h}$, for which a drug concentration of $17.118 \mathrm{~kg} / \mathrm{m}^{3}$ is left. The attenuation in the drug release rate is sustained for further timeframes. Drug concentrations of $15.208 \mathrm{~kg} / \mathrm{m}^{3}, 10.072 \mathrm{~kg} / \mathrm{m}^{3}$ and $3.7843 \mathrm{~kg} / \mathrm{m}^{3}$ are left as adsorbent for $t=24 h, t=48 h, t=96 h$, respectively. Drug release characteristic diverges from zero-order release kinetics while the corresponding graph approaches the full release condition. The concentration of the adsorbed drug $\left(\mathrm{C}_{\mathrm{A}}\right)$ is also graphically presented in Figure 4, along with the desorbed drug concentration $\left(\mathrm{C}_{\mathrm{B}}\right)$ on the nanofibrous mat. While adsorbed drug concentration increases, desorbed drug concentration, in contrast, decreases for the first six hours. Concentration values of $\mathrm{C}_{\mathrm{A}}=1.46 \mathrm{~kg} / \mathrm{m}^{3}$ and $\mathrm{C}_{\mathrm{B}}=229.98 \mathrm{~kg} / \mathrm{m}^{3}$ are obtained at $\mathrm{t}=6 \mathrm{~h}$. Afterward, $C_{A}$ decreases continuously, as $C_{B}$ does. It can be concluded that after a certain time point, which is approximately $\mathrm{t}=6 \mathrm{~h}$ for the present study, diffusion dominates adsorption-desorption as a release mechanism. $\mathrm{C}_{\mathrm{A}}$ disappears completely and $\mathrm{C}_{\mathrm{B}}$ approaches $31.17 \mathrm{~kg} / \mathrm{m}^{3}$ after 96 hours. 

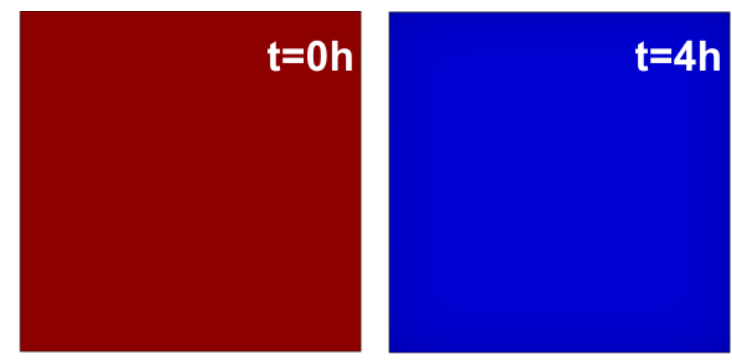

\section{$\mathrm{kg} / \mathrm{m}^{3}$}
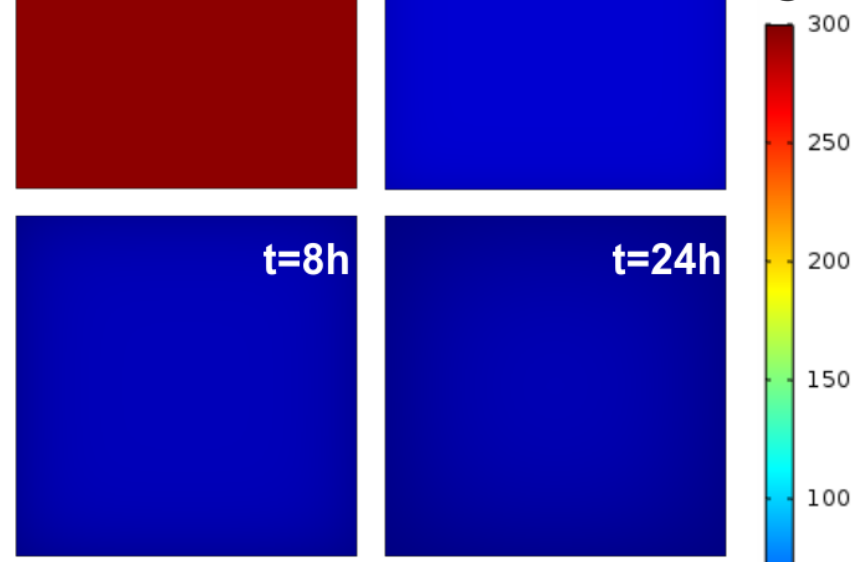

250
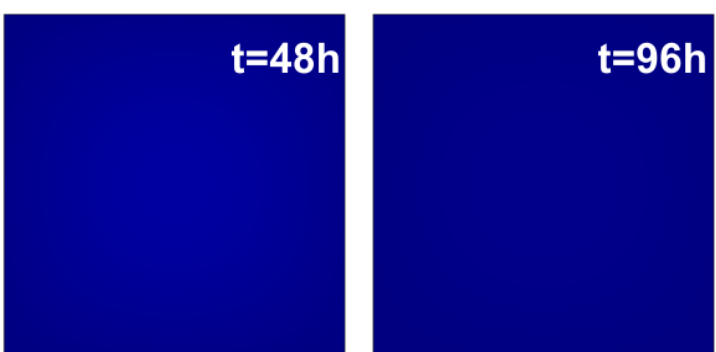

Figure 3. Concentration maps of adsorbed drug molecules on the nanofibrous mats for different timescales ( $\mathrm{h}=$ hour)

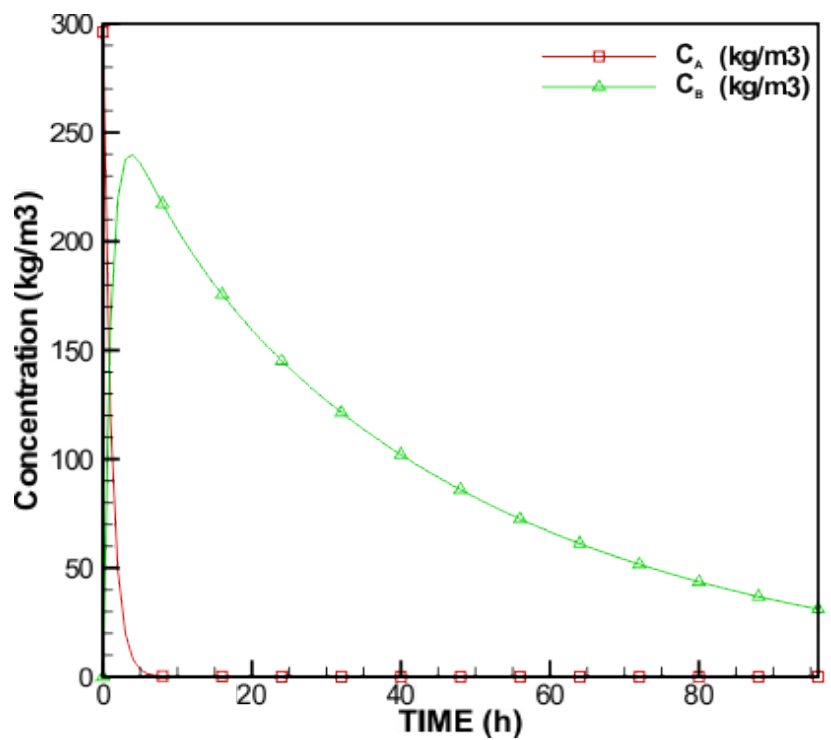

Figure 4. Transient concentrations of adsorbed and desorbed molecules on the nanofibrous mat 

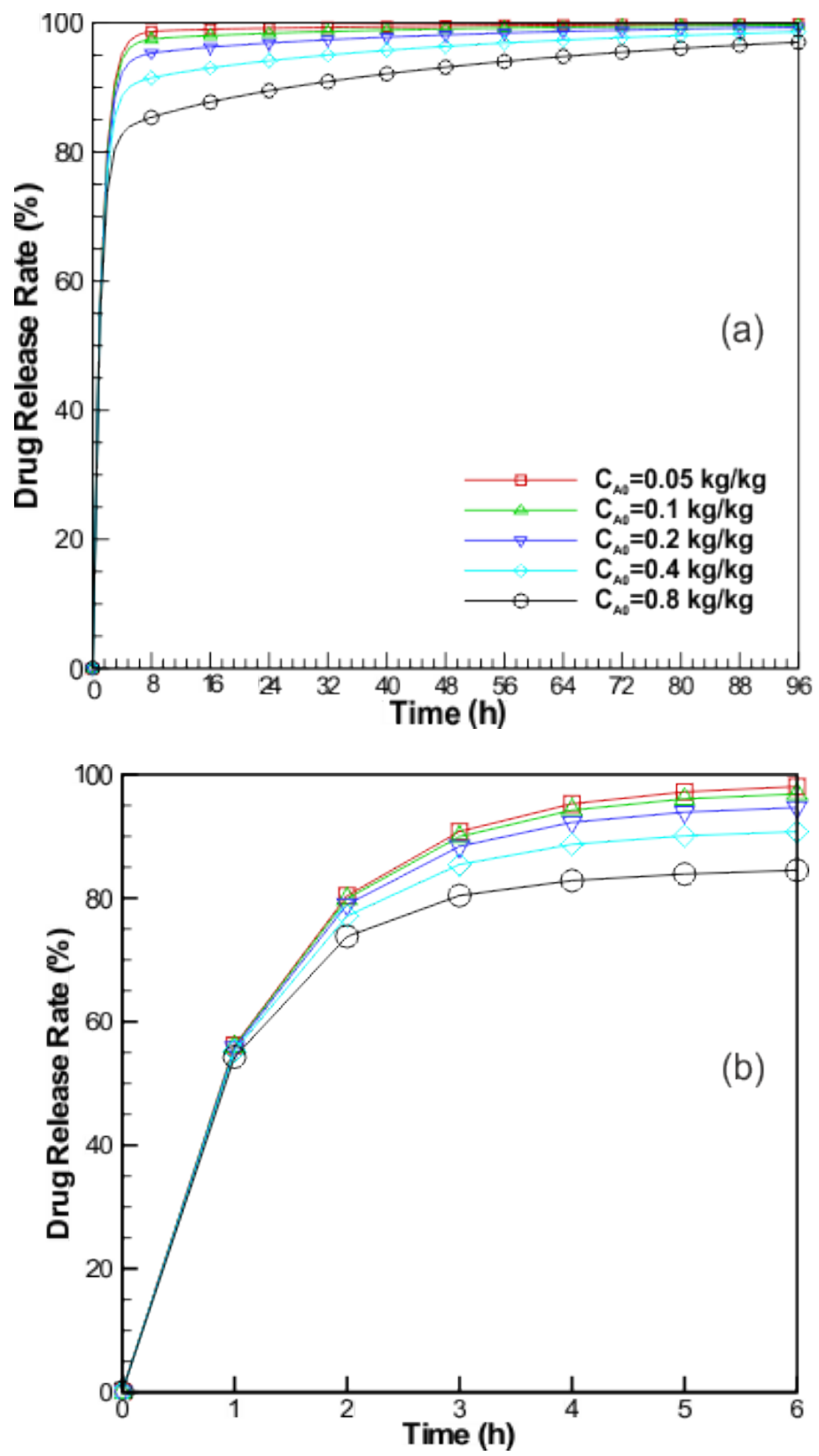

Figure 5. (a) Drug release rates for different initial drug concentrations within $96 \mathrm{~h}$. (b) Drug release rates for different initial drug concentrations within $6 \mathrm{~h}$

Initial drug concentration is significant for the drug release behavior, as graphically depicted in Figure 5a. When lower concentrations of the drug are loaded to the nanofibers, faster drug release is consistently observed, which agrees with the experimental study of Kabay et al. [32]. While $98.05 \%$ of the loaded drug is released for $\mathrm{C}_{\mathrm{A} 0}=0.05,84.5 \%$ of the loaded drug is released for $\mathrm{C}_{\mathrm{A} 0}=0.8$. Nearly full release, which is defined as a release rate higher than $99.5 \%$, is observed at 
$\mathrm{t}=46 \mathrm{~h}$ and $\mathrm{t}=78 \mathrm{~h}$ for $\mathrm{C}_{\mathrm{A} 0}=0.05$ and $\mathrm{C}_{\mathrm{A} 0}=0.1$, respectively. However, this rate is not reached via $\mathrm{C}_{\mathrm{A} 0}=0.2, \mathrm{C}_{\mathrm{A} 0}=0.4, \mathrm{C}_{\mathrm{A} 0}=0.8$, whose efficiencies are $99.31 \%, 98.57 \%$ and $97.01 \%$, respectively.

Porosity [33] is one of the most fundamental parameters for drug release studies. In electrospinning systems, porosity correlates with nanofiber density through nanofiber deposition duration on the scaffold. Since the drug is dissolved within the polymer solution, porosity is directly related to the initial drug concentration. As shown in Figure 6a, the initial drug mass decreases with increasing porosity. The porosity value of $\varepsilon=0.436$ is the base value in this study, which corresponds to an initial drug mass of $16.667 \mathrm{mg}$. When the porosity decreases twofold $(\varepsilon=0.218)$, the initial drug mass increases to $46.207 \mathrm{mg}$. On the other hand, if the porosity increases twofold ( $\varepsilon=0.654)$ and fourfold $(\varepsilon=0.872)$, the initial drug mass is calculated as $6.815 \mathrm{mg}$ and $1.891 \mathrm{mg}$, respectively. This finding is graphically displayed in Figure 6a. The influence of porosity variation on drug release rate is also investigated in the present work. As such, the drug release rate rises with increasing porosity, as seen in Figure $6 \mathrm{~b}$ and Figure $6 \mathrm{c}$. At $\mathrm{t}=6 \mathrm{~h}$, drug release rates of $88.13 \%$, $94.66 \%, 97.29 \%, 98.73 \%$ are obtained for the porosity values of $\varepsilon=0.218, \varepsilon=0.436, \varepsilon=0.654$, $\varepsilon=0.872$, respectively. Although, the nearly full release is observed for $\varepsilon=0.872$ and $\varepsilon=0.654$ at $\mathrm{t}=13 \mathrm{~h}$ and $\mathrm{t}=68 \mathrm{~h}$, respectively; $97.97 \%$ and $99.31 \%$ of drug release is reached for the systems with $\varepsilon=0.218$ and $\varepsilon=0.436$ at $100 \mathrm{~h}$ and $88 \mathrm{~h}$, respectively. It is known that the drug release rate is directly proportional to the porosity.
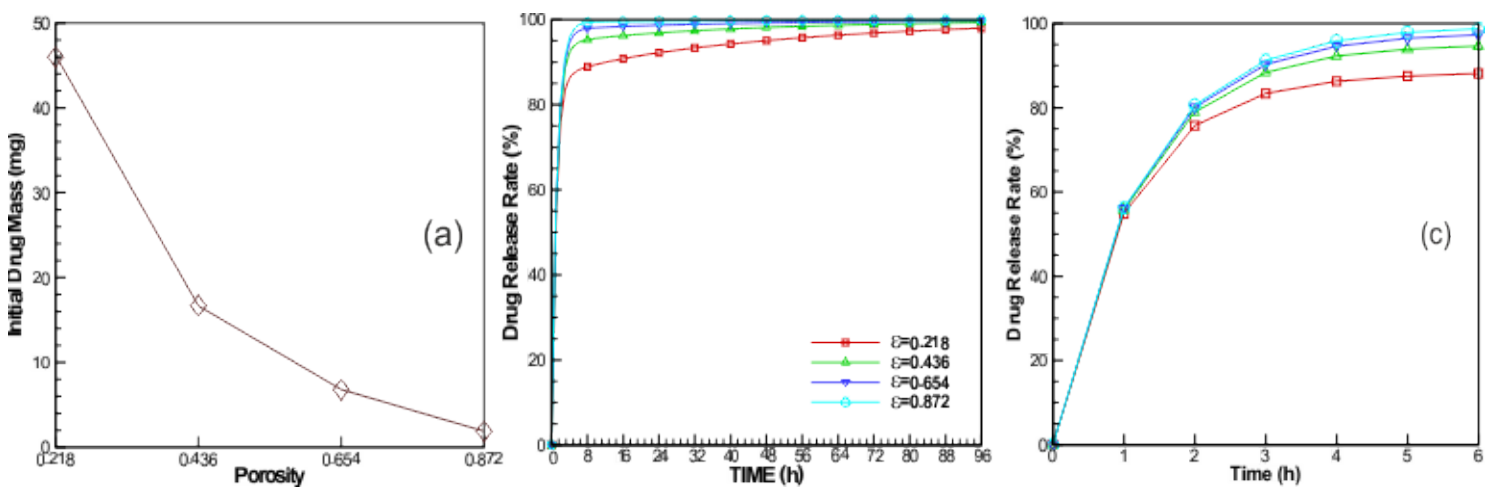

Figure 6. (a) Variations of initial drug concentrations for different porosity values. (b) Drug release rates for different porosity values within $96 \mathrm{~h}$. (c) Drug release rates for different porosity values within $6 \mathrm{~h}$

The results of the current numerical work also provide information about the effect of the permittivity coefficient on the drug relase. As seen in Figure 7, a slight decrease is observed in drug release rates with decreasing permittivity coefficients. For instance, drug release rates of $94.39 \%, 94.66 \%, 94.95 \%$ are acquired for $\mathrm{k}_{\mathrm{c}}=3.5 \times 10^{-8} \mathrm{~m} / \mathrm{s}, \mathrm{k}_{\mathrm{c}}=7 \times 10^{-8} \mathrm{~m} / \mathrm{s}, \mathrm{k}_{\mathrm{c}}=1.4 \times 10^{-7} \mathrm{~m} / \mathrm{s}$ at $\mathrm{t}=6 \mathrm{~h}$, respectively. When full release is obtained nearly for $\mathrm{k}_{\mathrm{c}}=1.4 \times 10^{-7} \mathrm{~m} / \mathrm{s}$ at $\mathrm{t}=92 \mathrm{~h}$, drug release rates of $99.31 \%$ and $98.81 \%$ are obtained for $\mathrm{k}_{\mathrm{c}}=7 \times 10^{-8} \mathrm{~m} / \mathrm{s}$ and $\mathrm{k}_{\mathrm{c}}=3.5 \times 10^{-8} \mathrm{~m} / \mathrm{s}$, respectively. It is also investigated whether the drug release rate is affected by the nanofibrous mat's surface area. The base surface area for the nanofibrous mat in this study is set to $A=2.25 \mathrm{~cm}^{2}$, which is halved as well as doubled and quadrupled in various analyses for parametric investigation. Initial drug concentration varies linearly with surface area, as shown in Figure 8a. However, no significant variations are observed for drug release rates with different surface areas, in contrast to the drug release from tablet matrices [34] or hydrogel coatings [35]. Nevertheless, more rapid drug release is observed for smaller surface areas, which is shown in Figures $8 \mathrm{~b}$ and $8 \mathrm{c}$. Drug release rates of $95.36 \%$, 
$94.66 \%, 94.41 \%, 94.29 \%$ are acquired for the surface areas of $\mathrm{A}=0.5625 \mathrm{~cm}^{2}, \mathrm{~A}=2.25 \mathrm{~cm}^{2}$, $\mathrm{A}=5.0625 \mathrm{~cm}^{2}, \mathrm{~A}=9 \mathrm{~cm}^{2}$ at $\mathrm{t}=6 \mathrm{~h}$, respectively. Moreover, nearly full release is reached only with
$\mathrm{A}=0.5625 \mathrm{~cm}^{2}$ at $\mathrm{t}=40 \mathrm{~h}$. Drug release rates of $99.31 \%, 98.24 \%, \% 97.46$ is carried out for $\mathrm{A}=2.25 \mathrm{~cm}^{2}, \mathrm{~A}=5.0625 \mathrm{~cm}^{2}, \mathrm{~A}=9 \mathrm{~cm}^{2}$ at $\mathrm{t}=96 \mathrm{~h}$, respectively.
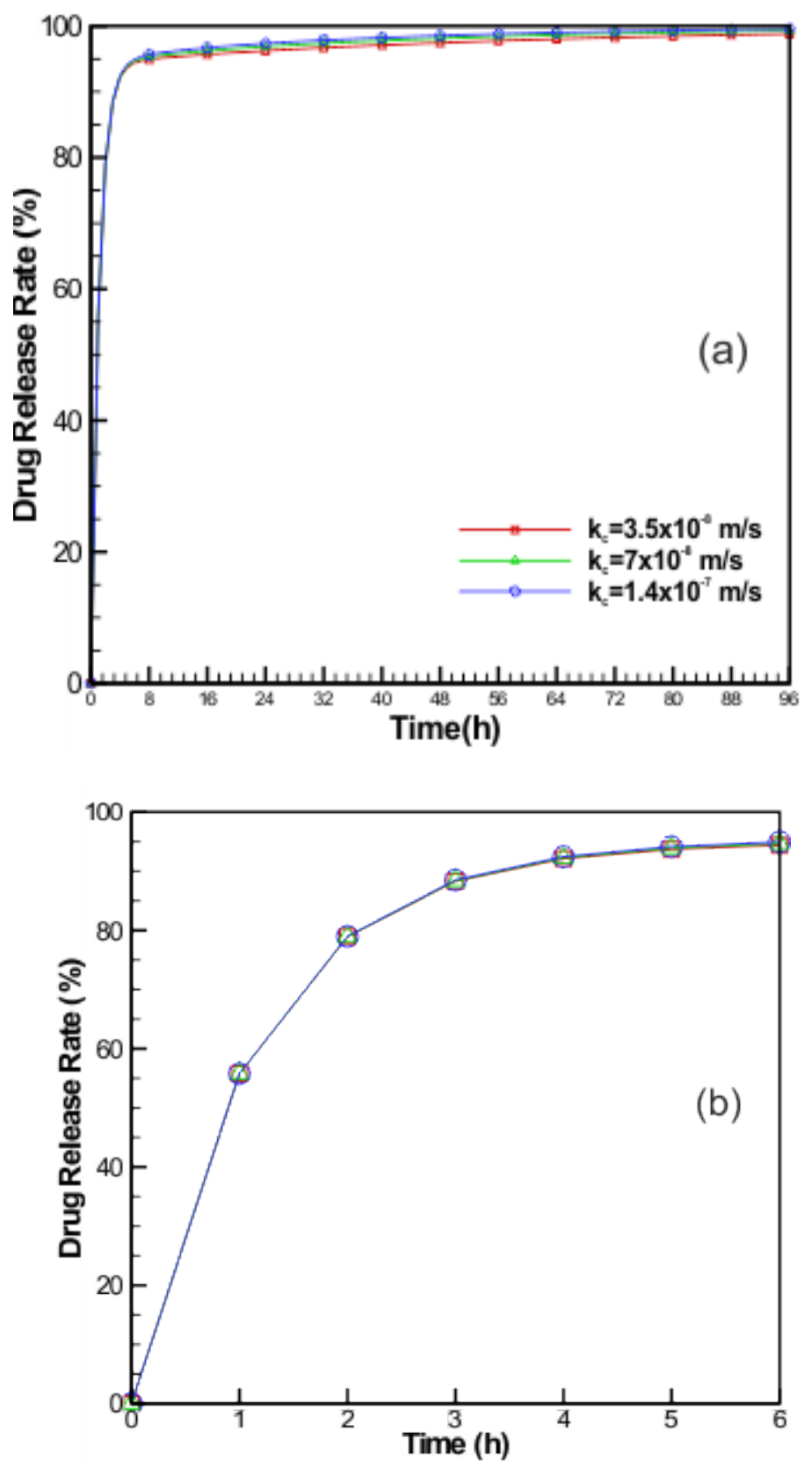

Figure 7. (a) Drug release rates for different permittivity coefficients within 96h. (b) Drug release rates for different permittivity coefficients within $96 \mathrm{~h}$ 

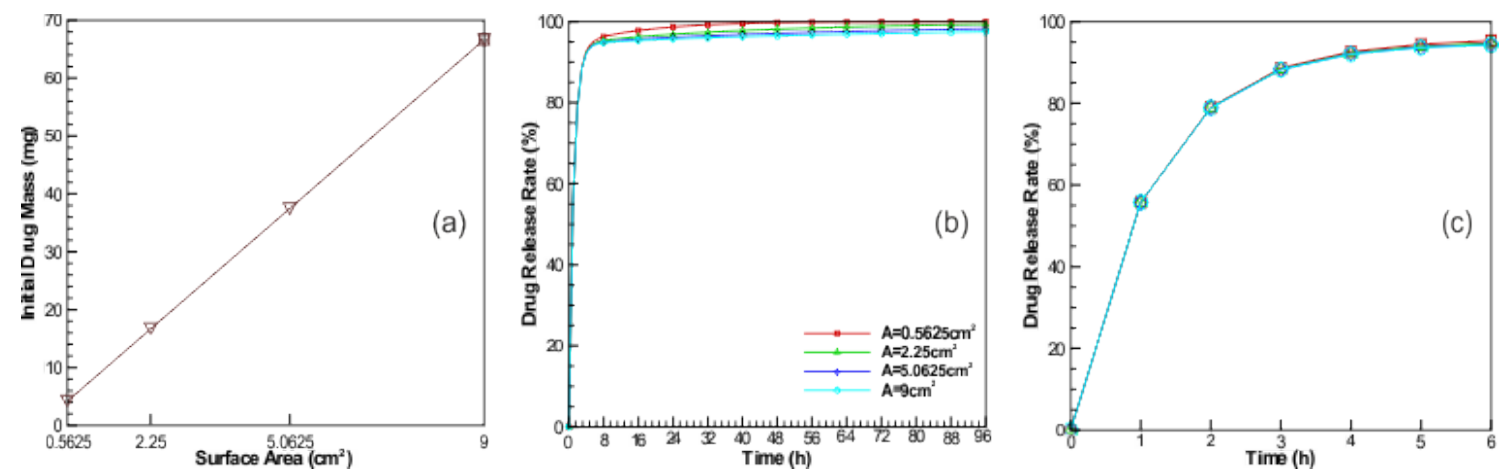

Figure 8. (a) Relationship between nanofibrous mat surface area and initial drug mass. (b) Drug release rates for varying surface areas within $96 \mathrm{~h}$. (c) Drug release rates for varying surface areas within $6 \mathrm{~h}$

\section{CONCLUSIONS}

In this study, drug release from nanofibrous mats is numerically analyzed. Although several experimental works are presented in the literature, comprehensive numerical studies are limited in this field. The following conclusions can be drawn from this study.

1. The experimental data are perfectly predicted by the current finite-element code.

2. The adsorbed drug is almost uniformly distributed throughout the nanofibrous mat surface, and burst release is observed initially.

3. Most of the drug molecules are desorbed within six hours.

4. More rapid drug release is achieved by means of lower concentrations of initial drug loading.

5. When the porosity decreases, initial drug mass increases due to enhanced nanofiber density.

6. The drug release rate can be accelerated by increasing the porosity.

7. The drug release rate can be increased by the rise of the permittivity coefficient or attenuating the nanofibrous mat's surface area.

\section{ACKNOWLEDGMENTS}

This work is supported by Cukurova University Scientific Research Office financially under contract no FBA-2017-7960 and FBA-201912419.

\section{REFERENCES}

1. Jaimini, M., Kothari, A.H., 2012. Sustained Release Matrix Type Drug Delivery System: A Review. J Drug Deliv Ther, 2(6), 142-148 https://doi.org/10.22270/jddt.v2i6.340.

2. Borgquist, P., Körner, A., Piculell, L., Larsson, A., Axelsson, A., 2006. A Model for the Drug Release from a Polymer Matrix Tablet-effects of Swelling and Dissolution. J Control Release, 113, 216-225.

3. Kuentz, M., Holm, R., Elder, D.P., 2016. Methodology of Oral Formulation Selection in the Pharmaceutical Industry. Eur J Pharm Sci, 87, 136-163.

4. Patel, H., Panchal, D.R., Patel, U., Brahmbhatt, T., Suthar, M., 2011. Matrix Type Drug Delivery System: A Review. J Pharm Sci Biosci Res, 1,143-151.

5. Tan, H.W., Xing, S.S., Bi, X.P., Li, L., Gong, H.P., Zhong, M., Zhang, Y., Zhang, W., 2008. Felodipine Attenuates Vascular Inflammation in a Fructose-induced Rat Model of Metabolic Syndrome Via the Inhibition of NF- $\kappa$ B Activation. Acta Pharmacol Sin, 29(9),1051-9.

6. Pitt, C.G., Schindler, A., 1995. The Kinetics of Drug Cleavage and Release from Matrices Containing Covalent Polymer-drug Conjugates. J Control Release, 33, 391-5.

7. Frenning, G., Fichtner, F., Alderborn, G., 2005. A New Method for Characterizing the Release of Drugs from Single Agglomerates. Chem Eng Sci, 60, 3909-18. 
8. Chou, S.F., Carson, D., Woodrow, K.A., 2015. Current Strategies for Sustaining Drug Release from Electrospun Nanofibers. Journal of Controlled Release, 220, 584-591.

9. Doshi, J., Reneker, D.H., 1995. Electrospinning Process and Applications of Electrospun Fibers. Journal of Electrostatics, 2, 151-160.

10.Zong, X., Kim, K., Fang, D., Ran, S., Hsiao, B.S., Chu, B., 2002. Structure and Process Relationship of Electrospun Bioabsorbable Nanofiber Membranes. Polymer, 43(16), 4403-4412.

11. Hamori, M.M., Shin, M., Rutledge, G., Brenner, M.P., 2001. Preparation and Pharmaceutical Evaluation of Nanofiber Matrix Supported Drug Delivery System Using the Solvent-based Electrospinning Method. Physics of Fluids, 13(8), 2201-2220.

12. Agarwal, S., Wendorff, J.H, Greiner, A., 2008. Use of Electrospinning Technique for Biomedical Applications. Polymer, 49, 5603-562.

13. Bedform, N.M., Steckl, A.J., 2010. Photocatalytic Self-Cleaning Textile Fibers by Coaxial Electrospinning. ACS Applied Materials \& Interfaces, 2(8), 2448-2455.

14. Aceituno-Medina, M., Mendoza, S., Lagaron, J.M., Loperz-Rubio, A., 2013. Development and Characterization of Food-grade Electrospun Fibers from Amaranth Protein and Pullulan Blends. Food Research International, 54(1), 667-674.

15. Hamori, M., Yoshimatsu, S., Hukuchi, Y., Shimizu, Y., Fukushima, K., Sugioka, N., Nishimura, A., Shibata, N., 2014. International Journal of Pharmaceutics, 464(1-2), 243-251.

16. Sun, B., Long, Y.Z., Chen, Z.J., Liu, S.L., Zhang, H.D., Zhang, J.C., Han, W.P., 2014. Recent Advances in Flexible and Stretchable Electronic Devices Via Electrospinning. Journal of Materials Chemistry C, 2, 1209-1219.

17. Liu, H., Edel, J.B., Bellan, L.M. Craighead, H.G., 2006. Electrospun Polymer Nanofibers as Subwavelength Optical Waveguides Incorporating Quantum Dots. Small, 2(4), 495-499.
18. Khil, M.S., Cha, D.I., Kim, H.K., Kim, I.S., Bhattarai, N., 2003. Electrospun Nanofibrous Polyurethane Membrane as Wound Dressing. Journal of Biomedical Materials Research Part B: Applied Biomaterials, 67B(2), 675-679.

19. Ren, X., Akdag, A., Zhu, C., Kou, L., Worley, S.D., 2009. Electrospun Polyacrylonitrile Nanofibrous Biomaterials. Journal of Biomedical Materials Research Part A, 91A(2), 385-390.

20. Ren, G., Xu, X., Liu, Q., Cheng J., Yuan, X., $\mathrm{Wu}$, L., Wan, Y., 2006. Electrospun Poly (vinyl alcohol)/glucose Oxidase Biocomposite Membranes for Biosensor Applications. Reactive and Functional Polymers, 66(12), 1559-1564.

21. Yoshimoto, H., Shin, Y.M., Terai, H., Vacanti, J.P., 2003. A Biodegradable Nanofiber Scaffold by Electrospinning and its Potential for Bone Tissue Engineering. Biomaterials, 24, 2077-2082.

22.Zhou, F.L., Hubbard, P.L., Eichborn, S.J., Parker, G.J.M., 2012. Coaxially Electrospun Axon-mimicking Fibers for Diffusion Magnetic Resonance Imaging. ACS Applied Materials \& Interfaces, 4, 6311-6316.

23. Hu, X., Liu, S., Zhou, G., Huang, Y., Xie, Z., Jing, X., 2014. Electrospinning of Polymeric Nanofibers for Drug Delivery Applications. Journal of Controlled Release, 185, 12-21.

24. Liang, D., Hsiao, B.S., Chu, B., 2007. Functional Electrospun Nanofibrous Scaffolds for Biomedical Applications. Advanced Drug Delivery Reviews, 59(14), 1392-1412.

25. Kenawy, E.R., Bowlin, G.L., Mansfield, K., Layman, J., Simpson, D.G., Sanders, E.H., Wnek, G.E., 2002. Release of Tetracycline Hydrochloride from Electrospun Poly (ethylene-co-vinylacetate), Poly (lactic acid), and a Blend. Journal of Controlled Release, 81(1-2), 57-64.

26.Zeng, J., Yang, L., Liang, Q., Guan, H., Xiuling, X., Chen, X., Jing, X., 2005. Influence of the Drug Compatibility with Polymer Solution on the Release Kinetics of Electrospun Fiber Formulation. Journal of Controlled Release, 105(1-2), 43-51.

27. Cui, W., Li, X., Zhu, X., Yu, G., Zhou, S., Weng, J., 2006. Investigation of Drug Release 
and Matrix Degradation of Electrospun Poly (dl-lactide) Fibers with Paracetanol Inoculation. Biomacromolecules, 7(5), 1623-1629.

28. Nakielski, P., Kowalczyk, T., Zembrzycki, K., Kowalewski, T.A., 2014. Experimental and Numerical Evaluation of Drug Release from Nanofiber Mats to Brain Tissue. Journal of Biomedical Materials Research B: Applied Biomaterials, 103B(2), 282-291.

29. Petlin, D.G., Amarah, A.A., Tverdokhlebov, S.I., Anissimov, Y.G., 2017. A Fiber Distribution Model for Predicting Drug Release Rates. Journal of Controlled Release, 258, 218-225.

30. Sultanova, Z., Kaleli, G., Kabay, G., Mutlu, M., 2016. Controlled Release of a Hydrophilic Drug from Coaxially Electrospun Polycaprolactone Nanofibers. International Journal of Pharmaceutics, 505, 133-138.

31.Lam, C.X.F., Savalani, M.M., Teoh, S.H., Hutmacher, D.W., 2008. Dynamics of in Vitro Polymer Degradation of PolycaprolactoneBased Scaffolds: Accelerated Versus Simulated Physiological Conditions. Biomedical Materials, 3(3), 034108.

32. Kabay, G., Meydan, A.E., Can Kaleli, G., Demirci, C., Mutlu, M., 2017. Controlled Release of a Hydrophilic Drug from Electrospun Amyloid-like Protein Blend Nanofibers. Materials Science \& Engineering C, 81, 271-279.

33. Tatlisoz, M.M., Demirturk, E., Canpolat, C., 2021. Release Characteristics of Gliclazide in a Matrix System. In Silico Pharmacol. 9, 12.

34. Frenning, G., Brohede, U., Stromme, M., 2005. Finite Element Analysis of the Release of Slowly Dissolving Drugs from Cylindrical Matrix Systems. Journal of Controlled Release, 107, 320-329.

35. Siepmann, J., Podual, K., Sriwongjanya, M., Peppas, N.A., Bodmeier, R., 1998. A New Model Describing the Swelling and Drug Release Kinetics from Hydroxypropyl Methylcellulose Tablets, Journal of Pharmaceutical Sciences, 88(1), 65-72. 